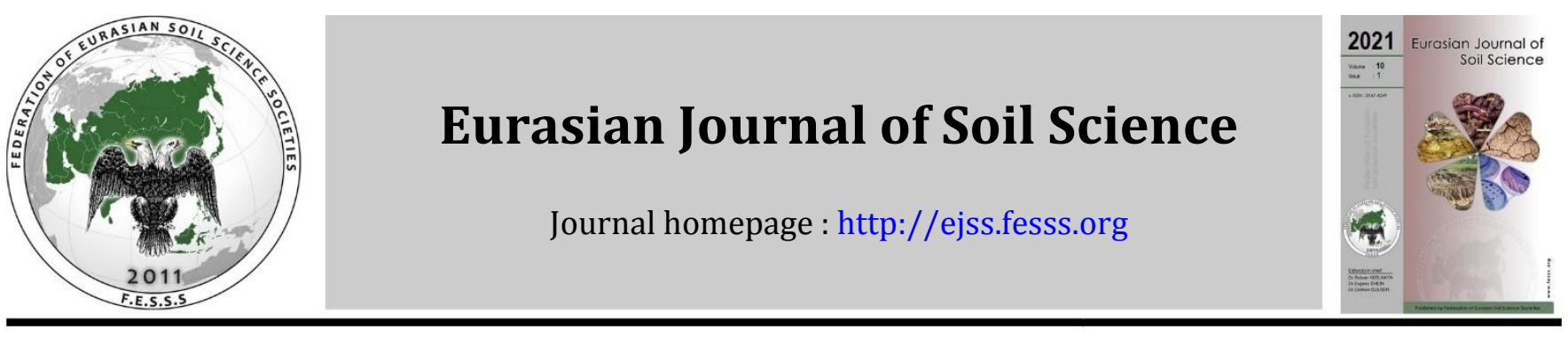

\title{
Spatio analysis of soil quality assessment in semi-arid ecosystem using a minimum data set İnci Demirağ Turan *
}

Samsun University, Faculty of Economic, Administrative and Social Sciences, Department of Geography, Samsun, Turkey

\section{Article Info}

Received : 05.10 .2020

Accepted : 30.03.2021

Available online : 10.04 .2021

\section{Author(s)}

İ.Demirağ Turan*

* Corresponding author

\section{Abstract}

Land degradation especially as a result of the rapid increase in demand and pressure in the population, have emerged as one of the most important problems. Many model approaches, especially regarding land degradation and desertification, have been developed and continue to be developed on the world. The MEDALUS (Mediterranean Desertification and Land Use) which is one of the famous models has been developed for an environment assessment program contributed to by 31 groups and 10 countries in 1999. This model includes the Environmental Sensitive Areas (ESA) index include climate, soil, land use-land cover, and management index. This current study aims to evaluate the soil quality indexes by using the total data set (TDS) and minimum data set (MDS) of the lands in Konya Basin, which is an arid and semiarid terrestrial ecosystem, with MEDALUS approach. The TDS consisted of nine soil quality parameters measured on 1019 samples: pH, Electrical Conductivity (EC), Organic Matter (OM), texture, $\mathrm{CaCO}_{3}$, depth, parent material, and slope. In addition, Principal components analysis (PCA) was used to determine which parameters were to be selected in the MDS. The MDS parameters consisted of slope, $\mathrm{pH}, \mathrm{OM}, \mathrm{CaCO}_{3}$. After those process, different interpolation models in order to create spatial distribution maps of parameters and SQI (Soil Quality Index). Results classified $13.59 \%$ of the total area has as low, while $84.110 \%$ of the study area' soil indicated area moderate by the SQI in terms of. Accordingly MDS, it was determined that $80.41 \%$ of the study area was in the mediumquality category, while only $2.01 \%$ was in the high-quality category. In the study area, minimum data set is seen that similar to the soil quality distribution in the total data set.

Keywords: Soil quality index, principal components analysis, arid-semi arid, Konya basin.

(C) 2021 Federation of Eurasian Soil Science Societies. All rights reserved

\section{Introduction}

In the last century, land degradation and desertification, especially as a result of the rapid increase in demand and pressure in the population, have emerged as one of the most important and irreversible environmental problems. This degradation leads to the loss of biological and economic productivity by the soil losing its functional property, which is one of the most important elements of the terrestrial ecosystem.

Land degradation is defined as the loss or reduction of biological and economic productivity resulting from land use in irrigated agricultural lands or pasture, forest, and scrublands in agricultural production dependent on rainfall or from human activities and natural consequences (United Nation, 1994). Major processes of land degradation are particularly the consequences of soil and vegetation degradation. When combined with excessive biophysical and socio-economic damages in arid areas, land degradation causes irreversible consequences leading to desertification. Therefore, land degradation is an environmental threat 
not only on a local or regional scale but also on a continental or even a global scale. According to the United Nations Convention to Combat Desertification (UNCCD, 2017), it has been estimated in recent studies that 1 to 6 billion hectares of land have already been degraded. In addition, according to estimates, this environmental problem will directly or indirectly threaten the welfare of more than 3 billion people in the world (IPBEE, 2018). Desertification is the degradation and impoverishment of arid and semi-arid terrestrial ecosystems as a result of climatic conditions and human activities (Kosmas et al., 1999a). Therefore, desertification and land degradation are among the most important problems of all countries. Accurately identifying areas susceptible to land degradation and desertification caused by both natural reasons and human activities is quite difficult due to the complex structure of nature. But despite all this difficulty, thanks to the recent scientific and technological developments, significant progress has been made as a result of studies that especially identify the characteristics of soils and reveal their spatial distribution. Many model approaches, especially regarding desertification and land degradation, have been developed and continue to be developed. As some examples of these approaches, (FAO-UNEP, 1984), model Turkmenistan (Babaev, 1985), GLASOD (Oldeman et al., 1991), DPSIR-FRAMEWORK (GIWA, 2001) can be given.

Another approach to identify areas susceptible to land degradation and desertification is the MEDALUS (Kosmas et al., 1999b) model. In order to investigate the negative effects of desertification and to take precautions, Mediterranean countries developed the project MEDALUS (Mediterranean Desertification And Land Use, (Kosmas et al., 1999b) carried out by the European Commission. Within the scope of the MEDALUS model, the environmentally sensitive areas index (ESA, Environmental Sensitive Areas) for sensitive areas at risk of desertification has been developed. The components that make up the ESA index are climate, soil, land use, and management (Bayramin, 2003; Salvati and Zitti, 2005). The MEDALUS model is widely used in many countries as it successfully yields the most dangerous areas regarding land degradation (De Paola et al., 2013; Allouche and Gad, 2014; Symeonakis et al., 2014; Prăvălie et al., 2017; Uzuner and Dengiz, 2020). The soil quality index in the MEDALUS model is one of the frequently used indices (Ozşahin et al., 2017). Studies are carried out on the soil quality index used in this model (Bayramin, 2003; Dengiz et al., 2004; Sepehr et al., 2007; Contador et al., 2009; Lahlaoi et al., 2017; Budak et al., 2018; Demirağ Turan et al., 2019).

Turkey is a country that is faced with land degradation and desertification at a significant level. We can list these risks as climate, topography, geology, vegetation, the characteristics of arable or non-arable land, pasture and forest areas, pasture grazing practices (overgrazing by sheep, goats, and cattle), arable land management, erosion, and population growth (Uzuner and Dengiz, 2020). In the study they carried out using 48 indicators and 37 sub-indicators, Türkeş et al. (2020) concluded that $12.7 \%$ of the land in Turkey was in the low-risk group, $53.2 \%$ in the medium-risk group, and $25.5 \%$ in the high-risk group. At least $15 \%$ of subbasins of Konya closed basin are at high risk of desertification (Türkeş et al. 2020). Besides, 32.2\% of Turkey's total land is in the low and very low category in terms of soil quality (Uzuner and Dengiz, 2020).

A total data set is formed with the parameters considered while determining the soil quality index. However, the minimum data set is created by making use of some approaches apart from the total data set in terms of time, cost and workload, especially obtaining data from large geographical areas in a short time. Moreover, Şeker et al (2017) reported that the use of minimum data sets in determining soil quality factors gives the best results in terms of economy, labor, and data quality produced. One of the most commonly used approaches to create a minimum data set is principal components analysis. Principal components analysis is widely used in order to reduce criteria in different areas (Shukla et al., 2006; Karaca et al., 2021). In this context, while Şenol et al. (2020) created minimum data set with soil texture, penetration resistance, available water capacity, $\mathrm{pH}$, and some plant nutrient elements for SQI, Uzner and Dengiz (2020) used soil texture, parent material slope, depth, drainage and coarse material as soil indicators for SQI based on MEDALUS

Semi-arid and arid areas, which are more vulnerable to environmental variations and are therefore more fragile, constitute about $65 \%$ of the total surface area of Turkey. These areas will be at higher risk of degradation in the near future because drought periods will be more frequent and severe due to global climate change (Kadığlu, 2012). The average annual precipitation is $300-350 \mathrm{~mm}$ in the region except for the southern parts of the Konya closed basin (İnan et al., 2006). In addition, Orhan and Ekercin (2015) reported that it was determined that surface temperature values increased between $2.00-3.00{ }^{\circ} \mathrm{C}$ in Konya closed basin between 1984 and 2011. In this sense, Konya Basin is getting sensitive from climate change and anthropogenic effects. This study aims to i) evaluate the soil quality indexes ii) compare SQI of the total and minimum data set of the lands in Konya Basin with MEDALUS approach. 


\section{Material and Methods}

\section{General features of the study area}

Konya Basin has an area of approximately $53,850 \mathrm{~km}^{2}$. The study area constitutes a considerable part of Central Anatolia. It is located between $36^{\circ} 55^{\prime} 15^{\prime \prime}-39^{\circ} 29^{\prime} 15^{\prime \prime}$ north latitudes and $31^{\circ} 19^{\prime} 26^{\prime \prime}-35^{\circ} 03^{\prime} 38^{\prime \prime}$ east longitudes and within the administrative borders of Konya, Ankara, Nevșehir, Aksaray, Niğde, Karaman, Mersin, Antalya, and Isparta (Figure 1). Its altitude varies between approximately 800-3400 m above sea level.

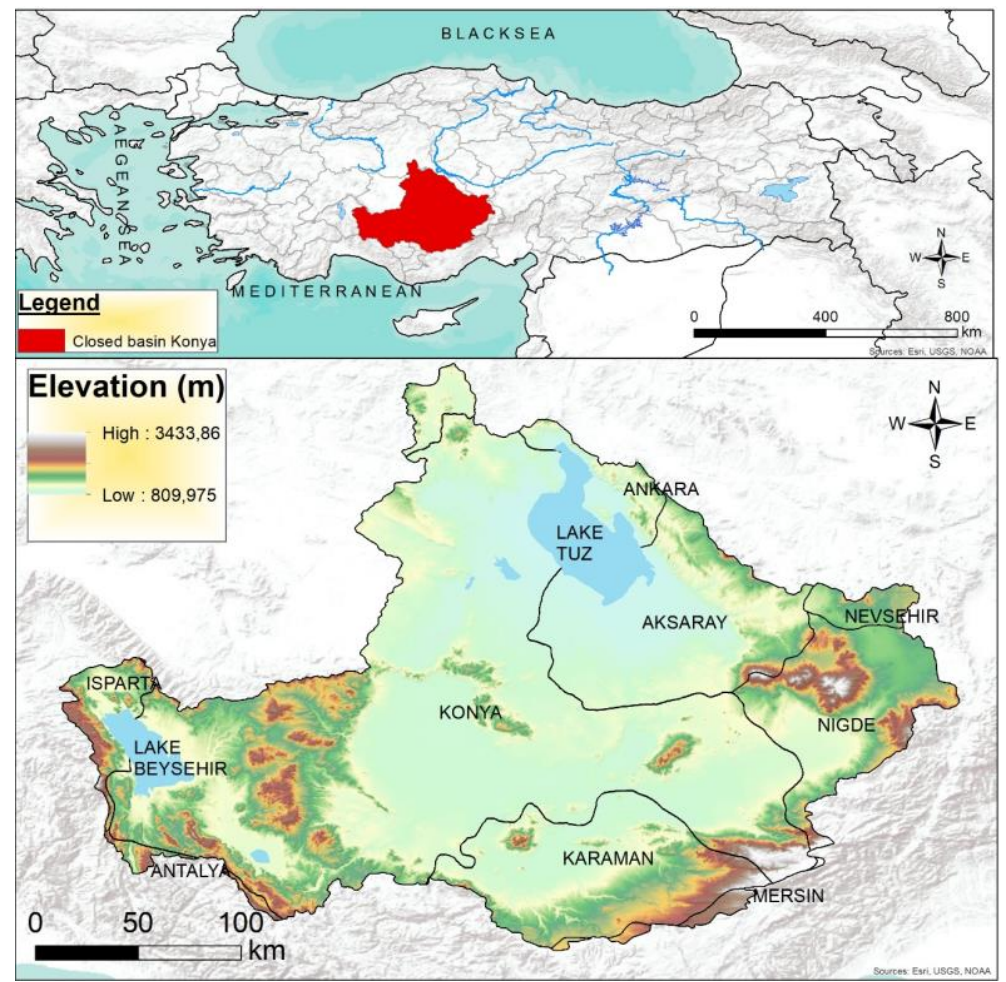

Figure 1. Location map of the study area

The fact that a decrease of $20-25 \mathrm{~mm}$ has been recorded in the basin compared to the normal rainfall over the years shows that the climate character has shifted from semi-arid climate type to arid climate type (Şen and Başaran, 2007). Average temperatures in the basin vary between $-0.4^{\circ} \mathrm{C}$ and $23^{\circ} \mathrm{C}$ annually (Yılmaz, 2010).

The land use/land cover distribution map of the study area according to CORINE 2018 is given in Figure 2, and the spatial and proportional distributions are given in Table 1 (European Environment Agency, 2018). Accordingly, the highest distribution is sparsely vegetated areas with an area of $8.625 \mathrm{~km}^{2}$. Green urban areas, sport and leisure facilities, rice fields, beaches, dunes, sands, and watercourses are the categories that take up the least space in the study area (Table 1).

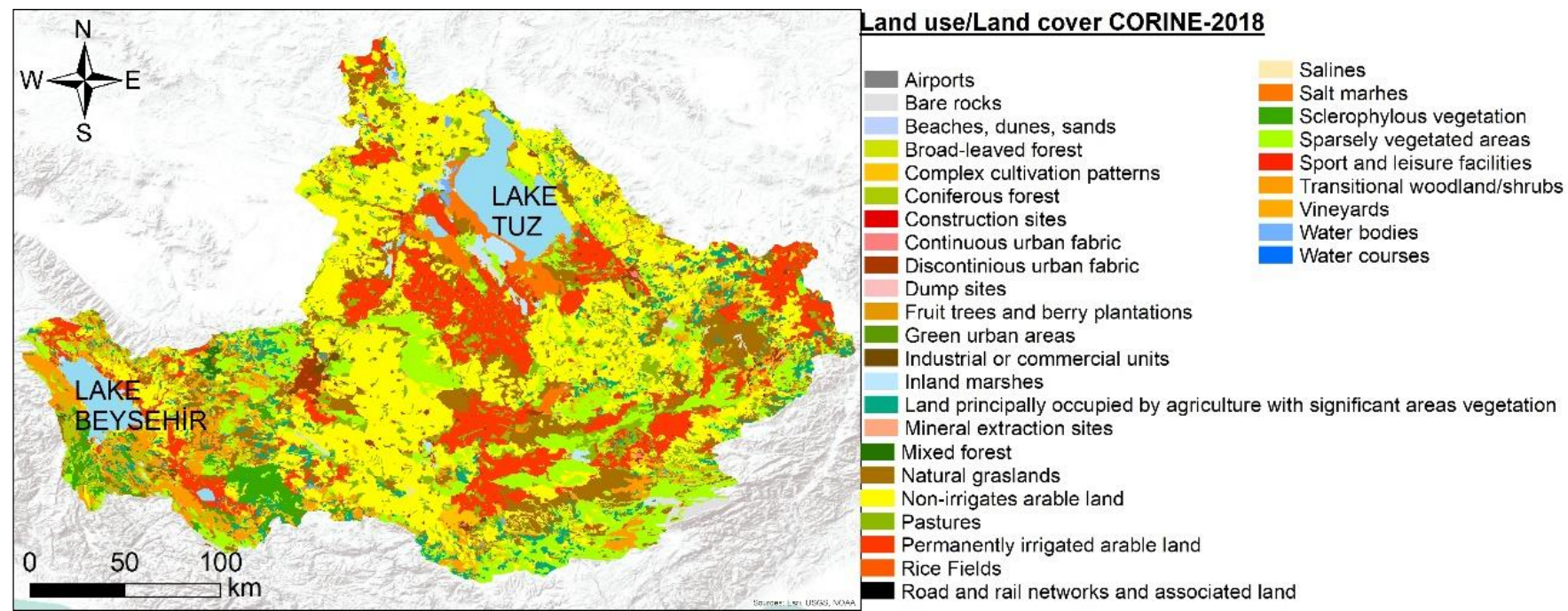

Figure 2. CORINE 2018 land use / land cover map of the study area. 
Table 1. Area and proportional distributions of CORINE 2018 land use / land cover

\begin{tabular}{|c|c|c|c|c|c|}
\hline Land use/ Land cover & $\mathbf{k m}^{2}$ & $\%$ & Land use/Land cover & $\mathbf{k m}^{2}$ & $\%$ \\
\hline Continuous urban fabric & 36 & 0.07 & Complex cultivation patterns & 3245 & 6.03 \\
\hline Discontinious urban fabric & 1012 & 1.88 & $\begin{array}{l}\text { Land principally occupied by agriculture } \\
\text { with significant areas vegetation }\end{array}$ & 4355 & 8.09 \\
\hline Industrial or commercial units & 349 & 0.65 & Broad-leaved forest & 254 & 0.47 \\
\hline $\begin{array}{l}\text { Road and rail networks and } \\
\text { associated land }\end{array}$ & 27 & 0.05 & Coniferous forest & 439 & 0.82 \\
\hline Airports & 32 & 0.06 & Mixed forest & 161 & 0.30 \\
\hline Mineral extraction sites & 24 & 0.04 & Natural graslands & 7271 & 13.50 \\
\hline Dump sites & 20 & 0.04 & Sclerophylous vegetation & 955 & 1.77 \\
\hline Construction sites & 51 & 0.09 & Transitional woodland/shrubs & 3922 & 7.28 \\
\hline Green urban areas & 3 & 0.01 & Beaches, dunes, sands & 5 & 0.01 \\
\hline Sport and leisure facilities & 4 & 0.01 & Bare rocks & 483 & 0.90 \\
\hline Non-irrigates arable land & 2642 & 4.91 & Sparsely vegetated areas & 8625 & 16.02 \\
\hline Permanently irrigated arable land & 7795 & 14.48 & Inland marshes & 498 & 0.92 \\
\hline Rice Fields & 5 & 0.01 & Salt marhes & 3616 & 6.71 \\
\hline Vineyards & 141 & 0.26 & Salines & 98 & 0.18 \\
\hline Fruit trees and berry plantations & 261 & 0.48 & Water courses & 4 & 0.01 \\
\hline \multirow[t]{2}{*}{ Pastures } & 4460 & 8.28 & Water bodies & 3057 & 5.68 \\
\hline & & & Total & 53850 & 100 \\
\hline
\end{tabular}

\section{Soil samples and physical and chemical analyses of soils}

Considering the topographic structure and land use status of the land, 1091 soil samples were taken randomly to represent each type of land and different topographic features (Figure 3). Soil depth at the sampling points was determined with the help of a auger. Soils were pounded and sieved through a 2-mm sieve to prepare them for physical and chemical analyses. The texture properties of soils were determined according to the Bouyoucos hydrometer method (Bouyoucos, 1962); soil reaction (pH) and electrical conductivity (EC) were with a glass electrode $\mathrm{pH}$ meter in the prepared 1: 2.5 soil-water mixture (Soil Survey Staff, 1992); lime contents were determined by Scheibler calcimeter (Soil Survey Staff, 1992); the organic matter was determined by the Walkley-Black method modified by Jackson (Jackson, 1958).

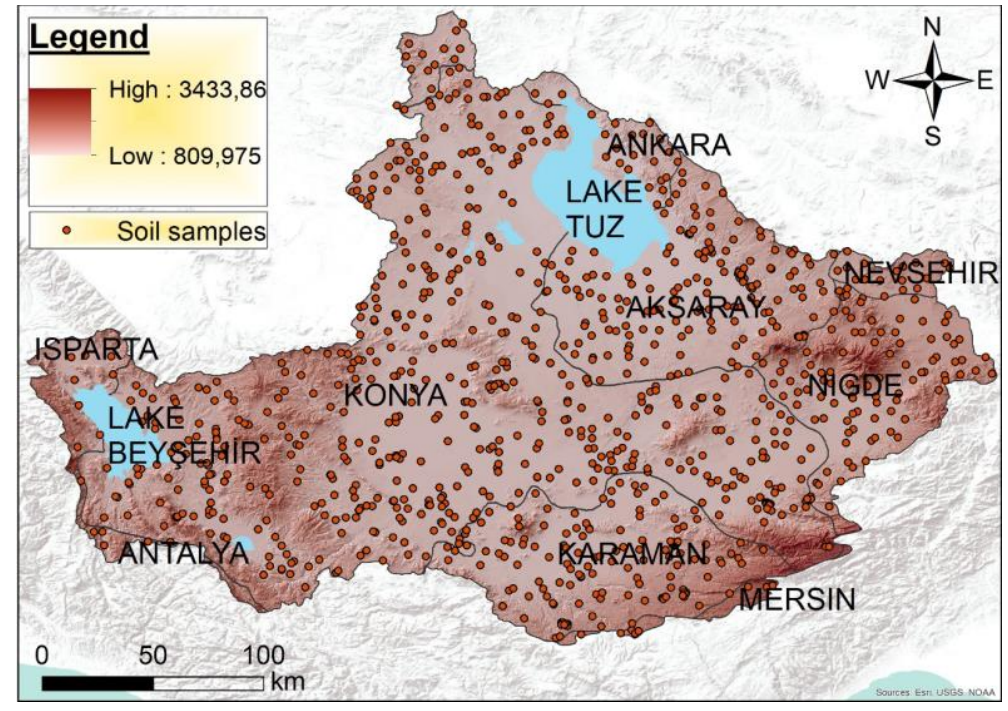

Figure 3. Soil sampling pattern on the study area

The slope map of the study area was produced from the digital elevation model with a scale of 1:25.000. In addition, the parent material parameter was determined by digitizing the 1: 25.000 scaled geology maps prepared by the General Directorate of Mineral Research and Exploration.

Interpolation methods were used to determine the spatial distribution of soil parameters and soil quality index for each point. Among the most used interpolation methods, deterministic methods of inverse distance weighting (IDW), radial basis functions (RBF), and kriging/cokriging methods from stochastic methods were preferred. The most commonly used methods in comparison of methods are root mean square error (RMSE), mean absolute error (MAE) are methods. For this study, RMSE was preferred, and 15 methods used for interpolation were compared. The method that yielded the lowest RMSE value was evaluated as the most suitable method. The following formula was used in the calculation of RMSE: 


$$
R M S E=\sqrt{\frac{\sum\left(z_{i^{*}}-z_{i}\right)^{2}}{n}}
$$

In the equation, $Z_{i}$ is estimated value, $Z_{i^{*}}$ is the measured value and $n$ refers to the number of samples.

\section{Determination of soil quality index}

The geometric mean of the scores obtained by soil quality index parameters included in the MEDALUS model helps determine the sensitivity of the lands to desertification. If the parameters defined in an area take high values, that land is defined as highly sensitive to desertification (Kosmas et al., 1999b). In this present study, besides the indicators for determining the soil quality index in the MEDALUS model, parameters such as organic matter, lime, electrical conductivity, and $\mathrm{pH}$ were added in order to increase the sensitivity in soil quality index value. The $\mathrm{pH}$ and lime content of soils were included in the soil quality index due to their effects on the usefulness of nutrients, organic matter content, and physical, chemical and biological properties of the soil. In addition, the EC parameter was added due to its effect on healthy plant growth. The scoring of these added soil properties was made using the studies of Kosmos et al. (1999b) (Table 2).

Table 2. Parameters and their index values used for SQI according to Kosmas et al. (1999b)

\begin{tabular}{|c|c|c|c|c|}
\hline & Classes & Evaluation & Description & İndex \\
\hline \multirow[t]{5}{*}{ Texture } & 1 & Very Good & $\mathrm{L}$ & 1.0 \\
\hline & 2 & Good & SCL, SiCL, CL & 1.2 \\
\hline & 3 & Moderate & SL, SiL, LS & 1.5 \\
\hline & 4 & Low & $\mathrm{SiC}, \mathrm{C}, \mathrm{SC}$ & 1.7 \\
\hline & 5 & Very Low & S, Si ve More than $60 \%$ Clay & 2.0 \\
\hline \multirow[t]{3}{*}{$\begin{array}{l}\text { Parent } \\
\text { Material }\end{array}$} & 1 & Good & $\begin{array}{l}\text { Shale, schist, basic and Ultra basic rocks } \\
\text { conglomerates non-cemented materials }\end{array}$ & 1.0 \\
\hline & 2 & Moderate & $\begin{array}{l}\text { Limestone, marble, granite, rhyolite, lgnibrite, } \\
\text { gneiss, silt stone, sandstone }\end{array}$ & 1.7 \\
\hline & 3 & Low & $\begin{array}{c}\text { Marl (for perennial plants the marl score should be } \\
1.0 \text { ), pyrosilicates }\end{array}$ & 2.0 \\
\hline \multirow{4}{*}{ Slope (\%) } & 1 & Slightly slope and flat & $<\% 6$ & 1.0 \\
\hline & 2 & Slightly slope & $\% 6-18$ & 1.2 \\
\hline & 3 & Steeply slope & $\% 18-35$ & 1.5 \\
\hline & 4 & Very Steeply slope & $>\% 35$ & 2.0 \\
\hline \multirow[t]{4}{*}{ Depth (cm) } & 1 & Deep & $>75 \mathrm{~cm}$ & 1.0 \\
\hline & 2 & Moderate & $75-30 \mathrm{~cm}$ & 1.33 \\
\hline & 3 & Shallow & $15-30 \mathrm{~cm}$ & 1.66 \\
\hline & 4 & Very shallow & $<15 \mathrm{~cm}$ & 2.0 \\
\hline \multirow{5}{*}{$\begin{array}{l}\text { EC }(\mathrm{dS} / \mathrm{m}) \\
\text { (Bakr et al., } \\
2012)\end{array}$} & 1 & Good & $<1.2$ & 1.0 \\
\hline & 2 & Slightly & $1.2-2,5$ & 1.2 \\
\hline & 3 & Moderate & $2.5-4,5$ & 1.5 \\
\hline & 4 & Saline & $4.5-9,0$ & 1.7 \\
\hline & 5 & Very saline & $>9.0$ & 2.0 \\
\hline \multirow[t]{8}{*}{ pH } & 1 & Very Strogly Acidic & $<5.0$ & 2.0 \\
\hline & 2 & Strongly Acidic & $5.1-5,5$ & 1.8 \\
\hline & 3 & Moderate Acidic & $5.6-6,0$ & 1.6 \\
\hline & 4 & Light Acidic & $6.1-6,5$ & 1.2 \\
\hline & 5 & Neutral & $6.6-7,3$ & 1.0 \\
\hline & 6 & Slightly alkaline & $7.4-8,0$ & 1.2 \\
\hline & 7 & Moderate Alkaline & $8.1-8,5$ & 1.6 \\
\hline & 8 & Strongly Alkaline & $>8.5$ & 2.0 \\
\hline \multirow[t]{8}{*}{ OM (\%) } & 1 & Very High & $>4.0$ & 1.0 \\
\hline & 2 & High & $3.0-4,0$ & 1.2 \\
\hline & 3 & Moderate & $2.0-3,0$ & 1.4 \\
\hline & 4 & Low & $1.0-2,0$ & 1.6 \\
\hline & 5 & Very Low & $0.5-1,0$ & 1.8 \\
\hline & 6 & Exremely Low & $<0.5$ & 2.0 \\
\hline & $\mathbf{1}$ & Very Less calcareous & $0-2$ & 1.4 \\
\hline & 2 & Less calcareous & $2-4$ & 1.2 \\
\hline \multirow{4}{*}{$\mathrm{CaCO}_{3}(\%)$} & 3 & Moderate calcareous & $4-8$ & 1.0 \\
\hline & 4 & Calcareous & $8-15$ & 1.2 \\
\hline & 5 & Very Calcareous & $15-30$ & 1.6 \\
\hline & 6 & Excessively Calcareous & $>30$ & 2.0 \\
\hline
\end{tabular}


The following formula is used for the soil quality index:

$$
\mathrm{SQI}_{\mathrm{TDS}}=\left(\text { Texture } * \text { Main material } * \text { Slope } * \text { Depth } * \mathrm{pH}^{*} \mathrm{OM}^{*} \text { Lime } * \mathrm{EC}\right)^{1 / 8}
$$

In the calculation of the soil quality index, the total data set including texture, parent material, slope, depth, $\mathrm{pH}, \mathrm{OM}$, lime, and EC were considered. From the total data set obtained, thematic maps were created separately for the parameters, and then the soil quality distribution of the study area was made by calculating with the geometric mean. After this process, the minimum data set was created with the help of principal components analysis (Doran and Parkin, 1994; Qi et al., 2009; Nabiollahi et al., 2017). As a result of the analysis, groups with eigenvalues equal to or greater than 1 were accepted as factors, and the critical factor load was taken as 0.5 (Wander and Bollero, 1999; Andrews et al., 2002). For each factor, it was determined that soil parameters with high factor loads are the most representative parameters and have absolute values at 10\% of the highest factor load (Sharma et al., 2005; Govaerts et al., 2006).

\section{Results and Discussion}

\section{Determination of interpolation model for spatial distribution}

Knowing the soil quality is important in terms of determining both desertification and land degradation and sustainable land use and soil management practices. While considering the parameters for soil quality, some physicochemical analyses were made on the 1019 soil samples collected from the study area. The lowest RMSE values among the 15 interpolation models in order to create spatial distribution maps of parameters considered are given in Table 3. Accordingly, for EC and pH, the Gaussian model of Natural Kriging was determined to be suitable, while RBF Completely Regularized Spline model was considered suitable for OM. RBF Spline With Tension was determined for lime, and a simple Kriging Spline With Tension model was identified for texture.

Table 3. Interpolation models and RMSE values applied for parameters.

\begin{tabular}{|c|c|c|c|c|c|c|c|}
\hline \multirow[t]{2}{*}{ Interpolation models } & & & \multicolumn{5}{|c|}{ Soil Parameters } \\
\hline & \multirow{2}{*}{\multicolumn{2}{|c|}{ IDW-1 }} & EC & $\mathrm{pH}$ & $\mathrm{OM}$ & $\mathrm{CaCO}_{3}$ & Texture \\
\hline \multirow{4}{*}{$\begin{array}{l}\text { Inverse Distance } \\
\text { Weighing (IDW) }\end{array}$} & & & 0.903 & 0.615 & 0.974 & 13.544 & 0.237 \\
\hline & \multicolumn{2}{|l|}{ IDW-2 } & 0.913 & 0.628 & 1.026 & 13.773 & 0.246 \\
\hline & \multicolumn{2}{|l|}{ IDW-3 } & 0.953 & 0.651 & 1.079 & 14.316 & 0.257 \\
\hline & \multicolumn{2}{|l|}{ TPS } & 28.111 & 0.903 & 3.957 & 24.478 & 0.426 \\
\hline \multirow{5}{*}{$\begin{array}{l}\text { Radial Basis Function } \\
(\mathrm{RBF})\end{array}$} & \multirow{2}{*}{\multicolumn{2}{|c|}{$\begin{array}{l}\text { CRS } \\
\text { SWT }\end{array}$}} & 0.894 & 0.613 & 0.973 & 13.245 & 0.260 \\
\hline & & & 0.891 & 0.615 & 0.975 & 13.217 & 0.252 \\
\hline & \multirow[t]{3}{*}{ Ordinary } & Gaussian & 0,877 & 0.611 & 1.008 & 14.058 & 0.235 \\
\hline & & Spherical & 0,887 & 0.618 & 1.006 & 13.329 & 0.233 \\
\hline & & Exponential & 0,881 & 0.617 & 1.008 & 13.607 & 0.234 \\
\hline \multirow[t]{6}{*}{ Kriging } & \multirow[t]{3}{*}{ Simple } & Gaussian & 0.901 & 0.626 & 0.989 & 14.080 & 0.234 \\
\hline & & Spherical & 0.902 & 0.622 & 0.976 & 13.231 & 0.232 \\
\hline & & Exponential & 0.906 & 0.621 & 0.982 & 13.695 & 0.233 \\
\hline & \multirow[t]{3}{*}{ Universal } & Gaussian & 0.878 & 0.627 & 1.008 & 14.058 & 0.235 \\
\hline & & Spherical & 0.887 & 0.612 & 1.006 & 13.329 & 0.233 \\
\hline & & Exponential & 0.881 & 0.617 & 1.008 & 13.607 & 0.234 \\
\hline
\end{tabular}

TPS:ThinPlateSplin, CRS: CompletelyRegularizedSpline, SWT: SplineWithTension OM: Organic matter, EC: Electrical Conductivity, $\mathrm{CaCO}_{3}$ : Lime

The spatial and proportional distributions of the parameters in the study area are given in Table 4 , and the distribution maps are presented in Figure 4. Accordingly, 23.8\% of the study area consists of deep soils. Deep soils spread over the lands in the basin base of the study area (Figure 4). An area of $42.3 \mathrm{~km}^{2}$ is in the medium category as the parent material. The medium category is widespread except in the south and southwest parts of the study area (Figure 4). In terms of texture, 62.9\% of the study area is in the good category, and in terms of the OM index category, $78.8 \%$ is in the very low category. $4.6 \mathrm{~km}^{2}$ area of the basin is in the very steep slope category and is spread over the mountainous areas surrounding the study area (Fig. 4). 74\% of the basin is in the good category in terms of EC. $63.2 \%$ of it constitutes a very calcareous area (Table 4). The lime ratio is quite high on the basin floor. In addition, it is in the medium alkaline category in terms of $\mathrm{pH}$, excluding the local areas in the east and west of the basin. This area constitutes approximately $74.4 \%$ of the area. 
Table 4. Spatial and proportional distributions of the study area soil parameters

\begin{tabular}{|c|c|c|c|c|c|c|c|c|c|c|c|}
\hline \multirow{2}{*}{$\begin{array}{l}\text { Soil depth } \\
\text { index }\end{array}$} & \multicolumn{2}{|c|}{ Area } & \multirow{2}{*}{$\begin{array}{l}\text { Parent } \\
\text { material } \\
\text { index }\end{array}$} & \multicolumn{2}{|c|}{ Area } & \multirow{2}{*}{$\begin{array}{l}\text { Texture } \\
\text { index }\end{array}$} & \multicolumn{2}{|c|}{ Area } & \multirow{2}{*}{$\begin{array}{l}\text { OM } \\
\text { index }\end{array}$} & \multicolumn{2}{|c|}{ Area } \\
\hline & $\mathbf{k m}^{2}$ & $\%$ & & $\mathbf{k m}^{2}$ & $\%$ & & $\mathbf{k m}^{2}$ & $\%$ & & $\mathbf{k m}^{2}$ & $\%$ \\
\hline 1.0: Deep & 12.8 & 23.8 & \multirow{4}{*}{$\begin{array}{l}1.0: \\
\text { Good } \\
1.7: \\
\text { Moderate }\end{array}$} & 11.6 & 21.5 & $\begin{array}{l}\text { 1.00: Very } \\
\text { good }\end{array}$ & 16.5 & 30.6 & $\begin{array}{l}\text { 1.2: } \\
\text { High }\end{array}$ & 0.8 & 1.5 \\
\hline $\begin{array}{l}\text { 1.33: } \\
\text { Moderate }\end{array}$ & 17.4 & 32.4 & & \multirow[t]{3}{*}{42.3} & \multirow[t]{3}{*}{78.5} & 1.2: Good & 33.9 & 62.9 & \multirow{3}{*}{$\begin{array}{l}\text { High } \\
1.4: \\
\text { Moderate } \\
1.8: \\
\text { Very low } \\
2.0 \text { : Extremely } \\
\text { low }\end{array}$} & 9.9 & 18.3 \\
\hline 1.66: Shallow & 9.9 & 18.4 & & & & $\begin{array}{l}\text { 1.5: } \\
\text { Moderate }\end{array}$ & 3.3 & 6.1 & & 42.5 & 78.8 \\
\hline $\begin{array}{l}\text { 2.0: Very } \\
\text { shallow }\end{array}$ & 13.7 & 25.5 & & & & 1.7:Low & 0.2 & 0.4 & & 0.7 & 1.3 \\
\hline Total & 53.9 & 100.0 & & 53.9 & 100.0 & Total: & 53.9 & 100.0 & Total & 53.9 & 100.0 \\
\hline \multirow{2}{*}{ EC index } & \multicolumn{2}{|c|}{ Area } & & \multicolumn{2}{|c|}{ Area } & Slope & \multicolumn{2}{|c|}{ Area } & & \multicolumn{2}{|c|}{ Area } \\
\hline & $\mathrm{km}^{2}$ & $\%$ & & $\mathbf{k m}^{2}$ & $\%$ & index & $\mathbf{k m}^{2}$ & $\%$ & & $\mathbf{k m}^{2}$ & $\%$ \\
\hline 1.0:Good & 39.9 & 74.1 & $\begin{array}{l}\text { 1.2: } \\
\text { Slightly } \\
\text { alkaline }\end{array}$ & 12.9 & 23.9 & $\begin{array}{l}\text { 1.0:Slightly } \\
\text { slope and } \\
\text { flat }\end{array}$ & 31.7 & 58.8 & $\begin{array}{l}1.2: \\
\text { Less } \\
\text { calcareous }\end{array}$ & 6.2 & 11.5 \\
\hline 1.2:Slightl & 12.2 & 22.7 & $\begin{array}{l}\text { 1.6: } \\
\text { Moderate } \\
\text { alkaline }\end{array}$ & 40.1 & 74.4 & $\begin{array}{l}\text { 1.2:Slightly } \\
\text { slope }\end{array}$ & 10.6 & 19.7 & $\begin{array}{l}\text { 1.6: Very } \\
\text { calcareous }\end{array}$ & 13.6 & 25.3 \\
\hline 1.5:Moderate & 1.8 & 3.2 & $\begin{array}{l}2.0: \\
\text { Strongly } \\
\text { alkaline }\end{array}$ & 0.9 & 1.7 & $\begin{array}{l}\text { 1.5: Steeply } \\
\text { slope }\end{array}$ & 7.0 & 13.0 & $\begin{array}{l}2.0: \\
\text { Excessively } \\
\text { calcareous }\end{array}$ & 34.0 & 63.2 \\
\hline 1.7:Saline & 0.0 & 0.0 & & & & $\begin{array}{l}\text { 2.0: Very } \\
\text { steeply } \\
\text { slope }\end{array}$ & 4.6 & 8.5 & & & \\
\hline Total & 53.9 & 100.0 & & 53.9 & 100.0 & Total & 53.9 & 100.0 & & 53.9 & 100.0 \\
\hline
\end{tabular}

\section{Distribution of the soil quality index in the Basin}

According to the MEDALUS model total soil quality index, soil texture, parent material, slope, depth, EC, $\mathrm{pH}$, organic matter, and lime parameters were used. Soil texture is thought to have a significant impact on soil quality. Soil texture affects soil water content and soil temperature (Chodak and Niklińska, 2010; Sugihara et al., 2010). Vinhal-Freitas et al. (2013) concluded in their study on Brazilian agricultural lands that soil texture plays an important role in soil quality indicators in Brazilian agricultural lands. Also Juhos et al. (2019) examined soil quality in agricultural lands in Central Europe by evaluating soil texture, groundwater table level, soil organic carbon, pH, calcium carbonate, electrical conductivity, sodium, nitrogen, phosphorus, potassium, sulfur, magnesium, copper, zinc, and manganese properties. In addition, by performing the principal components analysis in this study, soil texture, groundwater table level, soil organic carbon, $\mathrm{pH}$, sodium, potassium, phosphorus, and zinc were determined for the minimum data set. The texture parameter indices in the study area varied between 1.0 and 1.7 (Figure 4). It was determined that the texture category with a 1.2 index value showed wider distribution in the study area. Soils with this index value do not cause erosion by the surface flow of water reaching the soil with irrigation and rain. This shows that the resistance to desertification is high.

The parent material parameter index values were defined using the geological map of the study area. İn the study they conducted, Allouche and God (2014) evaluated the parent material, soil texture, depth, and slope characteristics while determining the soil quality in terms of water movement in the soil and its resistance to erosion. They concluded that $62.5 \%$ of the parent material in the study area was at a medium level in terms of soil erosion. Shale, schist, basic and ultrabasic rocks, and conglomerates and non-cemented materials were classified as good (1.0), while limestone and marble were classified as quite hard, and the parent materials such as granite, rhyolite, ignimbrite, gneiss, siltstone, and sandstone, which constitute soils with generally acidic character and low nutrient content when decomposed, were classified as medium (1.7). In the study area, the medium index value of the main material covers the most (42262 $\left.\mathrm{km}^{2}\right)$ area (Figure 4, Table 4). 

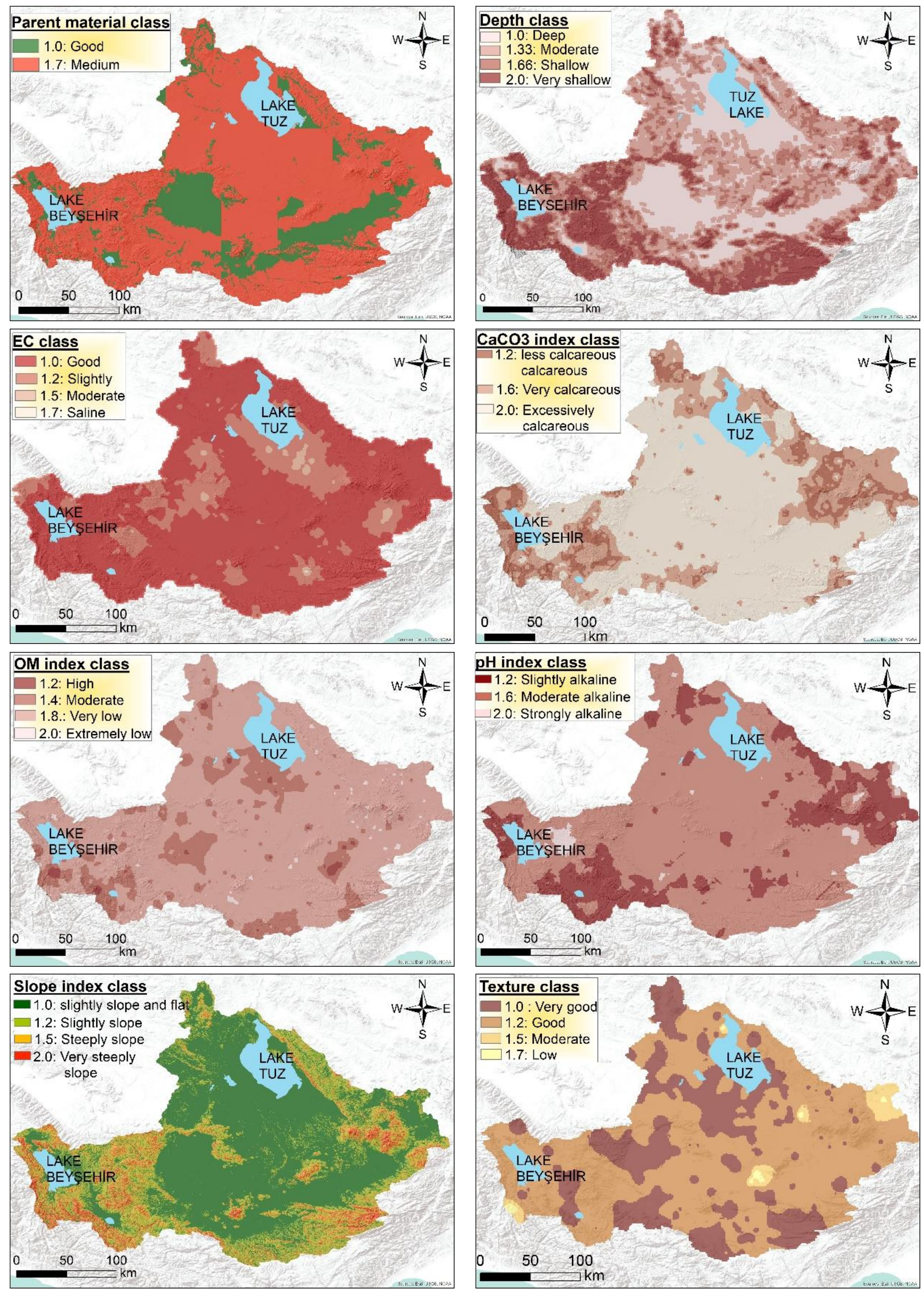

Figure 4. Distribution maps of soil parameters of the study area 
It is known that the slope parameter affects the variation of soil quality (Ayoubi et al., 2014; Fu et al., 2004; Raiesi, 2017; Khormali et al., 2019). Nabiollahi (2018) conducted field measurements in order to identify the effects of the slope on soil quality in agricultural lands. They reached the conclusion that low soil quality values were determined on slopes with high slope values and where land use was converted to agriculture, and that soil quality should be restored by adopting sustainable practices and abandoning excessive grazing in these areas. In their study, Paz-Kagan et al. (2016) revealed the soil quality by determining the physical, chemical, and biological properties of the soil. They investigated the effect of slope, exposure, land use, vegetation, and grazing density on soil quality, and the effects of each factor on the study areas were determined. Areas with severe erosion as a result of heavy and torrential rains are areas with high slope. While the agricultural lands on the floor of the Konya plain have low index values, the slope values increase in the high areas that form the surrounding forest areas (Figure 4). While $31.670 \mathrm{~km}^{2}(58.812 \%)$ of the study area is comprised of the areas where the slope values representing the plain floor are low, $4.600 \mathrm{~km}^{2}$ $(8.542 \%)$ of it has very steep slope values (Table 4).

Soil depth is important in terms of showing the stage of desertification. In many soil quality studies, soil depth has been taken as an important indicator of desertification (Mijangos and Garbisu, 2010; Salvati et al., 2011; Kladivko et al., 2014; de Paul Obade and Lal, 2016; Prăvălie et al., 2017). The European Environment Agency has mapped the soil quality of some southern European states using parameters based on the parent material, soil depth, texture, and slope (European Environment Agency, 2009). Kosmas et al. (1999b) stated in his study that soil depth decreases especially in arid/semi-arid lands, in areas vulnerable to erosion, or areas with heavy rainfall. The decrease in soil depth causes soil quality to decrease. $43,891 \mathrm{~km}^{2}$ of the study area, which is characterized by a semi-arid climate, has a shallow and very shallow index value (Figure 4, Table 4). The distribution of very and very shallow soils is observed in the mountainous areas around the Konya plain. On the floor land where the slope degree decreases towards the middle of the basin, deep soils are prevalent (Figure 4).

Using water that is not of suitable quality for irrigation or wrong irrigation techniques especially leads to land degradation and desertification through the salinization of agricultural land. As Kosmos et al. (1999a) has pointed out, increased concentrations of salts reduce the natural vegetation and weaken the functioning ability of soils. Increasing population, excessive agricultural activities, unconscious and excessive use of fertilizers, flood irrigation and the salt content of the water used to increase the salinity problems in the soils. Determination of soil's electrical conductivity (EC) is an important factor in revealing the soil character (Corwin and Lesh, 2005). Corwin et al. (2006) evaluated the management in soil quality with electrical conductivity (EC) values at soil sampling points in the study they conducted in central California. The results obtained in this research were an assessment of drainage water reuse and practices for EC on soil quality in central California. In their study, Johnson et al. (2001) determined the quality status and appropriate management system according to the EC category. According to the map obtained by the salinity indexes in the study area, there is no process as salinity causing desertification in the study area (Figure 4). 74.065\% of the study area is in the good category in terms of salinity. Especially the south of Tuz Gölü (Salt Lake) in the study area is in the saltier category in terms of salinity.

Soil pH is a significant soil parameter that plays a role in biotic and abiotic properties in the soil, especially in the nutrition of plants and affecting the usefulness of nutrients. In generally arid and semi-arid regions with high pH soil, the high calcium ions in the environment react with phosphates, and thus, plants are unable to take them (Sanyal and De Datta, 1991). Callesen et al. (2019) revealed the relationship between soil quality indicators, $\mathrm{pH}$, and sustainable forest management in Northern and Baltic forest soils. In the study conducted by Cotching and Kidd (2010), pH, organic carbon, extractable phosphorus, changeable sodium percentage, and aggregate stability were selected as soil quality indicators. According to the index values, it is seen that there are many problematic areas in the study area (Figure 4). The majority of the study area, $74.377 \%$, show a medium-alkaline property. In addition, the east of the study area and a portion of the western parts $\left(0.932 \mathrm{~km}^{2}\right)$ were determined to have high alkaline properties.

The chemical properties of the soil are very important in terms of yield and plant health (Franzluebbers and Stuedemann, 2009; Bhogal et al., 2011). Among the chemical properties, lime is an important parameter in terms of determining the usefulness of plant nutrients. Lime parameter is also used in soil quality studies (Abuzaid et al., 2021; Karaca et al., 2021). In their study, Santos-Francés et al. (2019) classified the indicators for soil quality as the best value, less good and optimal value. They stated that the lime content of $15 \%$ was the most suitable value. When we look at the distribution of lime in the study area, it is seen that the excessively calcareous soils cover an area of $34,020 \mathrm{~km}^{2}(63.175 \%)$. These areas are in the bottomlands of the study area. 
By evaluating all parameters together, a distribution map in the study area was produced with the soil quality index algorithm used in the MEDALUS method (Figure 5). Accordingly, while $45.293 \mathrm{~km}^{2}(84.110 \%)$ of the study area has medium quality, $13.59 \%$ of it has low quality soil distribution (Table 5).

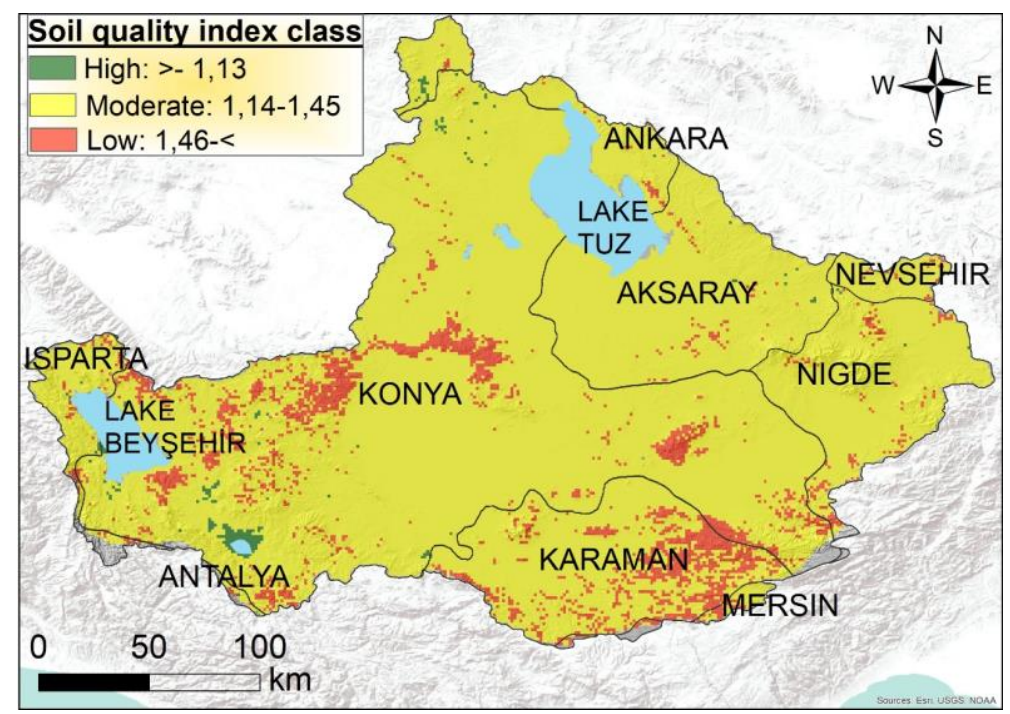

Figure 5. Soil quality map according to the total data set of the study area

Table 5. Soil quality index areal and proportional distribution of the study area

\begin{tabular}{ccccc}
\hline Class & Decription & index & Area $\left(\mathrm{km}^{2}\right)$ & Ratio $(\%)$ \\
\hline 1 & High & $>1.13$ & 1.235 & 2.293 \\
2 & Moderate & $1.14-1.45$ & 45.293 & 84.110 \\
3 & Low & $1.46<$ & 7.322 & 13.597 \\
\hline
\end{tabular}

In addition, a minimum data set was created in order to determine the most effective ones among the selected indicators, principal components analysis was performed in this regard. As a result, groups with eigenvalues equal to or greater than 1 were accepted as factors. 4 factors with eigenvalues greater than 1 were determined. According to the results obtained, $71.34 \%$ of the total change is explained by these factors (Table 6). When more than one indicator under a single factor has a high load, the correlation coefficient is checked for the minimum data set (Andrews et al., 2002). Variables with good correlations with each other are considered redundant, and one is considered for the minimum data set. In this study, when choosing the loads for the factors, the correlations between them were also examined (Table 7). The slope for the 1st factor after Varimax conversion has high loads. OM was the property with the highest load for factor 2, lime for factor 3, and pH for factor 4. Similarly, in the study conducted by Santos-Francés et al. (2019), lime and pH were found to be parameters with high factor loading. In their study, Karaca et al. (2021) formed the minimum data set of 26 parameters that they considered for soil quality from 8 parameters including $\mathrm{OM}$ and EC parameters.

Tablo 6. Results of Principal component for soil properties

\begin{tabular}{|c|c|c|c|c|}
\hline Principal component & 1 & 2 & 3 & 4 \\
\hline Eigenvalue & 1.590 & 1.220 & 1.100 & 1.000 \\
\hline Percent & 27.590 & 23.350 & 21.830 & 20.560 \\
\hline Cumulative percent & 29.590 & 44.950 & 58.780 & 71.340 \\
\hline \multicolumn{5}{|c|}{ Eigenvectors } \\
\hline Texture & 0.237 & -0.412 & 0.541 & 0.449 \\
\hline Parent Material & -0.509 & -0.227 & -0.179 & -0.340 \\
\hline Slope & 0.743 & -0.008 & -0.043 & -0.116 \\
\hline $\mathrm{pH}^{1}$ & 0.058 & 0.369 & -0.416 & 0.612 \\
\hline $\mathrm{CaCO}_{3}$ & -0.160 & 0.369 & 0.725 & -0.235 \\
\hline $\mathrm{OM}$ & -0.078 & 0.816 & 0.010 & -0.096 \\
\hline $\mathrm{EC}$ & -0.346 & 0.167 & 0.278 & 0.460 \\
\hline Deep & 0.738 & 0.200 & 0.068 & -0.154 \\
\hline
\end{tabular}

Bold factor loadings selected as MDS. 
Table 7. Correlation matrix of parameters

\begin{tabular}{lccllllll}
\hline & Texture & Parent Material & Slope & $\mathrm{pH}$ & $\mathrm{CaCO}_{3}$ & $\mathrm{OM}$ & $\mathrm{EC}$ & Deep \\
\hline Texture & 1.000 & & & & & & & \\
Parent Material & -0.053 & 1.000 & & & & & & \\
Slope & $0.089^{*}$ & $-0.174^{* *}$ & 1.000 & & & & & \\
$\mathrm{pH}$ & $-0.202^{* *}$ & 0.010 & 0.008 & 1.000 & & & & \\
$\mathrm{CaCO}_{3}$ & $-0.263^{* *}$ & $0.111^{* *}$ & $-0.284^{* *}$ & $0.223^{* *}$ & 1.000 & & & \\
$\mathrm{OM}$ & $-0.208^{* *}$ & -0.009 & $-0.169^{* *}$ & -0.001 & $0.232^{* *}$ & 1.000 & & \\
$\mathrm{EC}$ & -0.061 & $0.112^{* *}$ & $-0.148^{* *}$ & $-0.079^{*}$ & $0.106^{* *}$ & $0.200^{* *}$ & 1.000 & \\
Deep & -0.037 & $-0.290^{* *}$ & $0.436^{* *}$ & -0.050 & $-0.153^{* *}$ & -0.035 & $-0.222^{* *}$ & 1.000 \\
\hline
\end{tabular}

*: $\mathrm{p}<0.05$ level of significance, ${ }^{* *}: \mathrm{p}<0.01$ level of significance

The soil quality map for the minimum data set obtained was created by using an algorithm in the MEDALUS method again.

$$
\mathrm{SQI}_{\mathrm{MDS}}=\left(\text { Slope }^{*} \mathrm{pH}^{*} \mathrm{OM} * \text { Lime }\right)^{1 / 4}
$$

A soil quality distribution map was prepared in line with the MEDALUS model with the minimum data set (Figure 6). Accordingly, it was determined that $43.30 \mathrm{~km}^{2}(80.41 \%)$ of the study area was in the mediumquality category, while $1.08 \mathrm{~km}^{2}(2.01 \%)$ was in the high-quality category (Table 8$)$. In the study area, it is seen that the soil quality is low in Konya and Karaman provinces, similar to the soil quality distribution in the total data set. It was determined that there was significant parallelism between the soil quality maps created with both the total data set and the minimum data set obtained in line with the MEDALUS method.

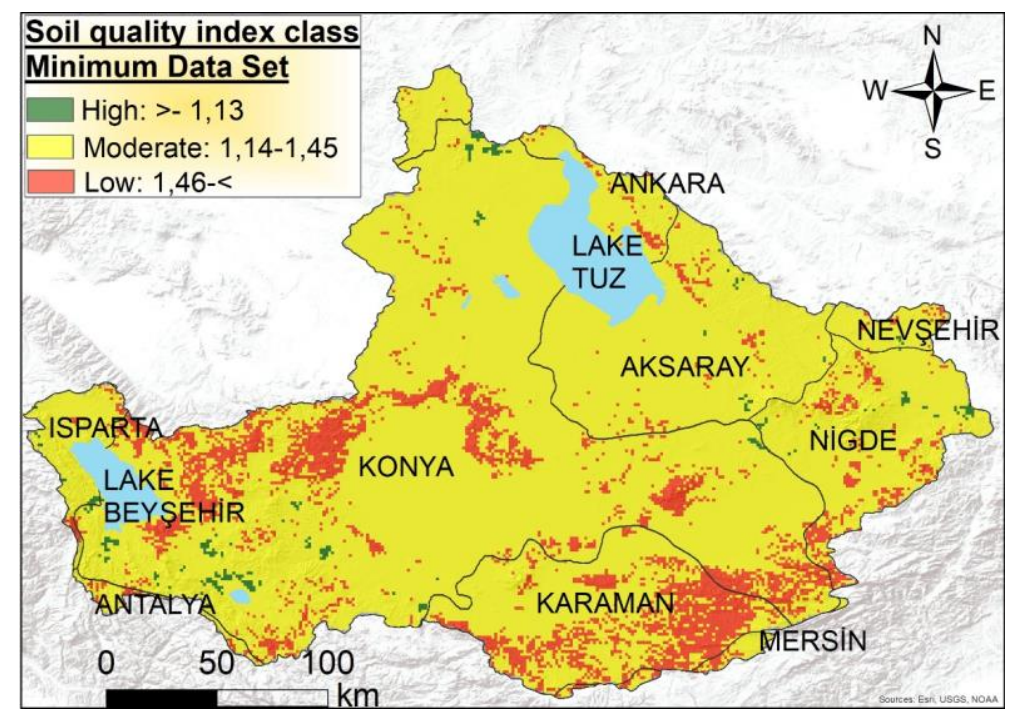

Figure 6. Soil quality map according to the minimum data set of the study area

Table 8. Soil quality index areal and proportional distribution according to the minimum data set of the study area

\begin{tabular}{ccccc}
\hline Class & Decription & index & Area $\left(\mathrm{km}^{2}\right)$ & Ratio $(\%)$ \\
2 & High & $>1.13$ & 1.08 & 2.01 \\
3 & Moderate & $1.14-1.45$ & 43.30 & 80.41 \\
\hline
\end{tabular}

\section{Conclusion}

Detailed soil quality studies are very important for sustainable soil management and determination of land degradation-desertification sensitivity. With this study, some physical and chemical properties of the soils in Konya Basin, which is a semi-arid region, were determined, and their distribution in the study area was identified by using interpolation methods. The soil quality index, which is an important component of the MEDALUS method, was determined both through the indicators included in the model and by adding some parameters that play important roles in the productivity functions of soils, and quality index categories of the study area were identified. Accordingly, $84.110 \%$ of the study area is in the medium category in terms of soil quality. The area of $7.322 \mathrm{~km}^{2}$ has low soil quality, and $1.235 \mathrm{~km}^{2}$ has high soil quality. Soil quality is 
lower around the settlements in the study area. In addition, the minimum data set was created with principal component analysis, and with the four parameters obtained, the soil quality distribution map was re-produced. Accordingly, $80.41 \%$ of the study area is in the medium category in terms of soil quality. 9.47 $\mathrm{km}^{2}$ of the area has low soil quality, and $1.08 \mathrm{~km}^{2}$ has high soil quality. When the soil quality index obtained from the total and minimum data sets was compared, it was determined that the compatibility was significantly high.

The results of this study are very important not only for regional scale but also for both nationally and internationally in terms of desertification. The results obtained can guide practices in this area in order to both minimize and reduce desertification processes. With this method, which allows the addition and subtraction of different parameters, by using different parameters in different areas, the soil quality risk studies on the scale of the basin can be pioneered.

\section{References}

Abuzaid, A.S., Abdellatif, A.D., Fadl, M.E., 2021. Modeling soil quality in Dakahlia Governorate, Egypt using GIS techniques. The Egyptian Journal of Remote Sensing and Space Science [in press]

Allouche, K.F., Gad, A., 2014. A comparison of methods for mapping the environmental sensitivity areas for desertification of a Mediterranean landscape using remote sensing and GIS applications. European Academic Research II(8): 10233-10253. Available at [Access date: 10.05.2020]: http://euacademic.org/UploadArticle/1070.pdf

Andrews, S.S., Karlen, D.L., Mitchell, J.P., 2002. A comparison of soil quality indices methods for vegetable production system in northern California. Agriculture, Ecosystems \& Environment 90: 25-45.

Ayoubi, A., Emami, N., Ghaffari, N., Honarjoo, N., Sahrawat, K.L., 2014. Pasture degradation effects on soil quality indicators at different hill slope positions in a semiarid region of western Iran. Environmental Earth Sciences 71: 375-381.

Babaev, A.G., 1985. Methodological principles of desertification processes assessment and mapping, Ashgabat, Turkmenistan. Desert Research Institute, Ashgabat, Turkmenistan. 72p.

Bayramin, İ., 2003. Beypazari topraklarinin MEDALUS metoduna göre toprak kalite indekslerinin belirlenmesi. Harran Üniversitesi Ziraat Fakültesi Dergisi 7 (3-4): 29-35. [in Turkish]

Bhogal, A., Nicholson, F.A., Young, I., Sturrock, C., Whitmore, A.P., Chambers, B.J., 2011. Effects of recent and accumulated livestock manure carbon additions on soil fertility and quality. European Journal of Soil Science 62(1): 174-181.

Bouyoucos, G.J., 1962. Hydrometer method improvement for making particle size analysis of soils. Agronomy Journal 54(5): 179-186.

Budak, M., Günal, H., Çelik, İ., Yıldız, H., Acir, N., Acar, M., 2018. Environmental sensitivity to desertification in northern Mesopotamia; application of modified MEDALUS by using analytical hierarchy process. Arabian Journal of Geosciences 11: 481.

Callesen, I., Clarke, N., Lazdinš, A., Varnagiryte-Kabasinskiene, I., Raulund-Rasmussen, K., 2019. Nutrient release capability in Nordic and Baltic forest soils determined by dilute nitric acid extraction - Relationships with indicators for soil quality, $\mathrm{pH}$ and sustainable forest management. Ecological Indicators 96: 540-547.

Chodak, M., Niklińska, M. 2010. Effect of texture and tree species on microbial properties of mine soils. Applied Soil Ecological 46: 268-275.

Contador, J.L., Schnabel, S., Gutiérrez, A.G., Fernández, M.P., 2009 Mapping sensitivity to land degradation in Extremadura. SW Spain. Land Degradation \& Development 20(2): 129-144.

Corwin, D.L., Lesch, S.M., 2005. Characterizing soil spatial variability with apparent soil electrical conductivity: Part II. Case study. Computers and Electronics in Agriculture 46(1-3): 135-152.

Corwin, D.L., Lesch, S.M., Oster, J.D., Kaffka, S.R., 2006. Monitoring management-induced spatio-temporal changes in soil quality through soil sampling directed by apparent electrical conductivity. Geoderma 131(3-4): 369 - 387.

Cotching, W.E., Kidd, D.B., 2010. Soil quality evaluation and the interaction with land use and soil order in Tasmania, Australia. Agriculture, Ecosystems and Environment 137(3-4): 358-366.

De Paola, F., Ducci, D., Giugni, M., 2013. Desertification and erosion sensivity. A case study southern Italy: the Tusciano river catchment. Environmental Earth Science 70: 2179-2190.

de Paul Obade, V., Lal, R., 2016. Towards a standard technique for soil quality assessment. Geoderma 265: 96-102.

Demiră̆ Turan, İ., Dengiz, O., Özkan, B., 2019. Spatial assessment and mapping of soil quality index for desertification in the semi-arid terrestrial ecosystem using MCDM in interval type-2 fuzzy environment. Computers and Electronics in Agriculture 164; 1004933.

Dengiz, O., Özden, Ş., Bașkan, O., Özcan, H., 2004. Determination of soil quality index of bala statefarm soils according to the medalus methodology. International Soil Congress on Natural Resource Management for Sustainable Development 7-10 June 2004, Erzurum, Turkey.

Doran, J.W., Parkin, B.T., 1994. Defining and assessing soil quality. In: Defining Soil Quality for a Sustainable Environment. Doran, J.W., Coleman, D.C., Bezdicek, D.F., Stewart, B.A. (Eds.). Soil Science Society of America Inc., Madison, WI, USA, pp. 3-21. 
European Environment Agency, 2009. Indices of climate, soil and vegetation quality. Available at [Access date: 10.05.2020]: https://www.eea.europa.eu/data-and-maps/data/indices-of-climate-soil-and-vegetation-quality-1

European Environment Agency, 2018. CORINE Land Cover. Available at [Access date: 10.05.2020]: https://www.eea.europa.eu/publications/COR0-landcover/at_download/file

FAO-UNEP, 1984. Provisional methodology for assessment and mapping of desertification. Food and Agriculture Organization of the United Nations /United Nations Environmental Programme. Rome, Italy. 84p.

Franzluebbers, A.J., Stuedemann, J.A., 2009. Soil-profile organic carbon and total nitrogen during 12 years of pasture management in the Southern Piedmont USA. Agriculture, Ecosystems and Environment 129(1-3): 28-36.

Fu, B.J., Liu, S.L., Chen, L.D., Lu, Y.H., Qiu, J., 2004. Soil quality regime in relation to land cover and slope position across a highly modified slope landscape. Ecological Research 19: 111-118.

GIWA, 2001. DPSIR framework for state of environment reporting (Driving Forces-Pressures-State-ImpactsResponses). Global International Water Assessment, European Environment Agency. 104p.

Govaerts, B., Sayre, K.D., Deckers, J., 2006. A minimum data set for soil quality assessment of wheat and maize cropping in the highlands of Mexico. Soil and Tillage Research 87: 163-174..

İnan, N., Şen, E., Başaran, N., 2006. Konya Ovasının İklimi. Devlet Meteoroloji İşleri Genel Müdürlüğü No: 4, Ankara, Turkey. [in Turkish]

IPBES, 2018. The assessment report on land degradation and restoration. Summary for policymakers. Available at [Access date: 10.05.2020]: https://ipbes.net/sites/default/files/spm_3bi_ldr_digital.pdf

Jackson, M.L., 1958. Soil Chemical Analysis, Prentice Hall Inc. Englewood Cliffs, New Jersey, USA. 498p.

Johnson, C.K., Doran, J.W., Duke, H.R., Weinhold, B.J., Eskridge, K.M., Shanahan, J.F., 2001. Field-scale electrical conductivity mapping for delineating soil condition. Soil Science Society America Journal 65(6): 1829 - 1837.

Juhos, K., Czigány, S., Madarász, B., Ladányi, M., 2019. Interpretation of soil quality indicators for land suitability assessment - A multivariate approach for Central European arable soils. Ecological Indicators 99: 261-272.

Kadıŏ̆lu, M., 2012. Türkiye'de İklim Değişikliği Risk Yönetimi. Türkiye'nin İklim Değişikliği II. Ulusal Bildiriminin Hazırlanması Projesi Yayını. T.C. Çevre ve Şehircilik Bakanlığı, Ankara, Turkey. 172p. [in Turkish]

Karaca, S., Dengiz, O., Demirağ Turan, İ., Özkan, B., Dedeoğlu, M., Gülser, F., Sargin, B., Demirkaya, S., Ay, A., 2021. An assessment of pasture soils quality based on multi-indicator weighting approaches in semi-arid ecosystem. Ecological Indicators 121: 107001.

Khormali, F., Ajami, A., Ayoubi, S., Srinivasarao, C.H., Wani, S.P., 2009. Role of deforestation and hillslope position on soil quality attributes of loess-derived soils in Golestan province, Iran. Agriculture, Ecosystems and Environment 134: $178-189$.

Kladivko, E.J., Helmers, M.J., Abendroth, L.J., Herzmann, D., Lal, R., Castellano, M.J., Mueller, D.S., Sawyer, J.E., Anex, R.P., Arritt, R.W., Basso, B., Bonta, J.V., Bowling, L.C., Cruse, R.M., Fausey, N.R., Frankenberger. J.R., Gassman, P.W., Gassmann, A.J., Kling, C.L., Kravchenko, A., Lauer, J.G., Miguez, F.E., Nafziger, E.D., Nkongolo, N., O'Neal, M., Owens, L.B., Owens, P.R., Scharf, P., Shipitalo, M.J., Strock, J.S., Villamil, M.B., 2014. Standardized research protocols enable transdisciplinary research of climate variation impacts in corn production systems. Journal of Soil and Water Conservation 69(6): 532-542.

Kosmas, C., Gerontidis, St., Detsis, V., Zafiriou, Th., Marathianou, M., 1999b. The island of Lesvos (Greece). In: The MEDALUS Project: Mediterranean desertification and land use. Manual on key indicators of desertification and mapping environmentally sensitive areas to desertification. Kosmas, C., Kirkby, M., Geeson, N., (Eds.). European European Commission, Community Research, Project Report. pp.66-73. Available at [Access date: 10.05.2020]: http://www.comap.ca/kmland/display.php?ID=253\&DISPOP=VRCPR

Kosmas, C., Kirkby, M.J., Geeson, N., 1999a. The MEDALUS Project: Mediterranean desertification and land use. Manual on key indicators of desertification and mapping environmentally sensitive areas to desertification. European European Commission, Community Research, Project Report. 88p. Available at [Access date: 10.05.2020]: http://www.comap.ca/kmland/display.php?ID=253\&DISPOP=VRCPR

Lahlaoi, H., Rhinane, H., Hilali, A., Lahssini, S., Moukrim, S., 2017. Desertification assessment using MEDALUS model in watershed Oued El Maleh, Morocco. Geosciences 7(3): 50.

Mijangos, I., Garbisu, C., 2010. Consequences of soil sampling depth during the assessment of the effects of tillage and fertilization on soil quality: a common oversight. Soil and Tillage Research 109(2): 169-173.

Nabiollahi, K., Golmohamadi, F., Taghizadeh-Mehrjardi, R., Kerry, R., Davari, M., 2018. Assessing the effects of slope gradient and land use change on soil quality degradation through digital mapping of soil quality indices and soil loss rate. Geoderma 318: 16-28.

Nabiollahi, K., Taghizadeh-Mehrjardi, R., Kerry, R., Moradian, S., 2017. Assessment of soil quality indices for salt-affected agricultural land in Kurdistan Province, Iran. Ecological Indicators 83: 482-494.

Oldeman, L.R., Hakkelingr, T.A., Sombroek, W.G., 1991. World Map of the Status of Human-induced Soil Degradation (GLASOD): An explanatory note. International Soil Reference and Information Centre (ISRIC)/ United Nations Environment Programme (UNEP), Nairobi, Kenya. 27p.

Orhan, O., Ekercin, S., 2015. Konya kapalı havzasında uzaktan algılama ve CBS teknolojileri ile iklim değişikliği ve kuraklık analizi. TUFUAB VIII. Teknik Sempozyumu 21-23 Mayıs 2015, Konya, Turkey. [in Turkish]

Ozsahin, E., Pektezel, H., Eroglu, I., 2017. Soil quality index (SQI) analysıs of Tekirdag province using GIS (Thrace, Turkey). Fresenius Environmental Bulletin 26(4): 3005-3014. 
Paz-Kagan, T., Ohana-Levi, N., Herrmann, I., Zaady, E., Henkin, Z., Karnieli, A., 2016. Grazing intensity effects on soil quality: A spatial analysis of a Mediterranean grassland. Catena 146: 100-110.

Prăvălie, R., Săvulescu, I., Patriche, C., Dumitraşcu, M., Bandoc, G., 2017. Spatial assessment of land degradation sensitive areas in southwestern Romania using modified MEDALUS method. Catena 153: 114-130.

Qi, Y., Darilek, J.L., Huang, B., Zhao, Y., Sun, W., Gu, Z. 2009. Evaluating soil quality indices in an agricultural region of Jiangsu Province, China. Geoderma 149(3-4): 325-334.

Raiesi, F., 2017. A minimum data set and soil quality index to quantify the effect of land use conversion on soil quality and degradation in native rangelands of upland arid and semiarid regions. Ecological indicators 75: $307-320$.

Salvati, L., Bajocco, S., Ceccarelli, T., Zitti, M., Perini, L., 2011. Towards a process-based evaluation of land vulnerability to soil degradation in Italy. Ecological Indicators 11 (5): 1216-1227.

Salvati, L., Zitti, M., 2005. Land degradation in the Mediterranean basin: Linking biophysical and economic factors into an ecological perspective. Biota - International Journal of Biology and Ecology 5: 67- 77.

Santos-Francés, F., Martínez-Graña, A., Ávila-Zarza, C., Criado, M., Sánchez, Y., 2019. Comparison of methods for evaluating soil quality of semiarid ecosystem and evaluation of the effects of physico-chemical properties and factor soil erodibility (Northern Plateau, Spain). Geoderma 354: 113872.

Sanyal, S.K., De Datta, S.K., 1991. Chemistry of Phosphorus Transformations in Soil. In: Advances in Soil Science. Stewart, B.A. (Ed.). Springer-Verlag, New York, USA. pp. 1-120

Sepehr, A., Hassanli, A.M., Ekhtesasi, M.R., Jamali, J.B., 2007. Quantitative assessment of desertification in south of Iran using MEDALUS method. Environmental Monitoring and Assessment 134: 243.

Sharma, K.L., Mandal, U.K., Srnivas, K., Vittal, K.P.R., Mandal, B., Grace, J.K., Ramesh, V. 2005. Long-term soil management effects on crop yields and soil quality in a dryland Alfisol. Soil and Tillage Research 83(2): 246-259.

Shukla, M.K., Lal, R., Ebinger, M., 2006. Determining soil quality indicators by factor analysis. Soil and Tillage Research 87(2): 194-204.

Soil Survey Staff, 1992. Procedures for Collecting Soil Samples and Methods of Analysis For Soil Survey. Soil Surv. Invest. Rep. I. U.S. Gov. Print. Office, Washington D.C., USA.

Sugihara, S., Funakawa, S., Kilasara, M., Kosaki, T., 2010. Effect of land management and soil texture on seasonal variations in soil microbial biomass in dry tropical agroecosystems in Tanzania. Applied Soil Ecology 44: 80-88.

Symenoakis, E., Karathanasis, N., Koukoulas, S., Panagopoulos, G., 2014. Monitoring sensitivity to land degradation and desertification with the environmentally sensitive area index: the case of Lesvos island. Land Degradation and Development 27(6): 1562-1573.

Şeker, C., Özaytekin, H.H., Neğis, H., Gümüş, İ., Dedeoğlu, M., Atmaca, E., Karaca, Ü., 2017. Identification of regional soil quality factors and indicators: a case study on an alluvial plain (central Turkey). Solid Earth 8(3): 583-595.

Şen, E., Başaran, N., 2007. Küresel isınma sürecinde Konya Ovasının bazı iklim verilerinde meydana gelen değişmeler ve eğilimler. Uluslararası Küresel İklim Değişikliği ve Çevresel Etkileri Konferansı. 18-20 Ekim 2007. Konya, Turkey. [in Turkish]

Şenol, H., Alaboz, P., Demir, S., Dengiz, O., 2020. Computational intelligence applied to soil quality index using GIS and geostatistical approaches in semiarid ecosystem. Arabian Journal of Geosciences 3:1235.

Türkes, M., Öztas, T., Tercan, E., Erpul, G., Karagöz, A., Dengiz, O., Doğan, O., Şahin, K., Avcıŏlu, B., 2020. Desertification vulnerability and risk assessment for Turkey via an analytical hierarchy process model. Land Degradation Development 31(2): 205-214.

UNCCD, 2017. United Nations Convention to Combat Desertification. Global Land Outlook first edition (2017) Available at [Access date: 10.05.2020]: https://knowledge.unccd.int/glo/GLO_first_edition

United Nations, 1994. Elaboration of an international convention to combat desertification in countries experiencing serious drought and/or desertification, particularly in Africa. Final text of the Convention. Available at [Access date: 10.05.2020]: https://wedocs.unep.org/handle/20.500.11822/27569

Uzuner, Ç., Dengiz, O., 2020. Desertification risk assessment in Turkey based on environmentally sensitive areas. Ecological Indicators 114,106295.

Vinhal-Freitas, I.C., Ferreira, A.S., Corrêa, G.F., Wendling, B., 2013. Land use impact on microbial and biochemical indicators in agroecosystems of the Brazilian Cerrado. Vadose Zone Journal 12(1): 1-8.

Wander, M.M., Bollero, G.A., 1999. Soil quality assessment of tillage impacts in Illinois. Soil Science Society of America Journal 63(4): 961-971.

Yılmaz, S., 2010. Havza Koruma Eylem Planlarının Hazırlanması Projesi Konya Kapalı Havzası. TÜBİTAK Marmara Araştırma Merkezi Çevre Enstitüsü, Proje Nihai Raporu 5098115 ÇE.10.49. [in Turkish] 